\title{
ANALISA INVESTASI KEUANGAN DAN PENGARUHNYA TERHA- DAP KINERJA PERUSAHAAN SEKTOR PERHOTELAN
}

\author{
Taufik Hidayat \\ Sekolah Tinggi Ilmu Ekonomi dan \\ Bisnis Perdana Mandiri (STIEB) Purwakarta, Indonesia \\ mercy_thidayat@yahoo.com
}

\begin{abstract}
The study was conducted to analyze the hotel performance focusing on the financial aspect. This is critical for the hotel since they have done building renovation financed by the bank, therefore controlling the financial activities will assist the hotel debt return in the long run. The financial analysis used some tools such as Break Event Point (BEP), Internal Rate of Return (IRR), Revenue Cost Ratio (RCR), Return On Investment (ROI), Return On Equity (ROE), Cost Benefit Ratio (CBR) dan Profitability Index to measure the hotel's performance. The result shows that NPV>0 then investment with NPV Rp. 39.36 billion can be continued safely. The Break event point (BEP) is accepted for 8 years. The Internal Rate of Return (IRR) method is used to analyze the amount of interest that makes the cost of expenditure and income equal to the size of IRR Hotel XYZ 15.87\%> 8.5\% (interest deposit bank) where IRR > i (interest rate), so investment proposal accepted. The RCR (Revenue Cost Ratio) method is 1.17 in 2012, amounting to 1.20 in 2013 and amounting to 1.38 in 2014 which explains that $R / C>1$ is profitable after the project. The ROI (Return on Investment) was explained that there was an increase in the ability of Hotels in obtaining operating profit from invested capital in all assets. ROE (Return on Equity) explained that there was an increase in the ability of XYZ Hotels to obtain net income from paid-up capital. The Profitability Index (PI) method of $1.656>1$ then the building renovation of the hotel can be continued and profitable.
\end{abstract}

Keywords: Break Event Point (BEP), Internal Rate of Return (IRR), Revenue Cost Ratio (RCR), Return On Investment (ROI), Return On Equity (ROE), Cost Benefit Ratio (CBR) dan Profitability Index 


\section{I.1. LATAR BELAKANG PENELITIAN}

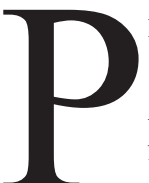
rovinsi Banten merupakan salah satu provinsi dengan potensi pariwisata yang paling lengkap. Memiliki keindahan alam yang mempesona baik pegunungan, laut (Dinas Pariwisata Daerah Provinsi Banten Tahun 2013).

Pemerintah Kota Cilegon dalam mendukung kepariwisataan dan keperluan bisnis diperlukan sarana akomodasi yang cukup representatif untuk melayani kebutuhan penginapan bagi wisatawan dan pelaku bisnis.

Hasil survey Hotel tahun 2013 oleh BPS Kota Cilegon, jumlah tamu yang menggunakan fasilitas Hotel berbintang sebanyak 60.266 orang sedangkan 37.388 orang menggunakan fasilitas Hotel non bintang. Laju pertumbuhan subsektor Hotel tahun 2013 mengalami peningkatan yang cukup berarti sebesar 4,33 persen, lebih rendah dari tahun sebelumnya sebesar 4,39 persen. Kondisi ini didukung dengan peningkatan sektor industri menengah dan besar sebanyak 77 perusahaan yang menjadi primadona perekonomian Kota Cilegon.

\section{PERTUMBUHAN EKONOMI 2013}

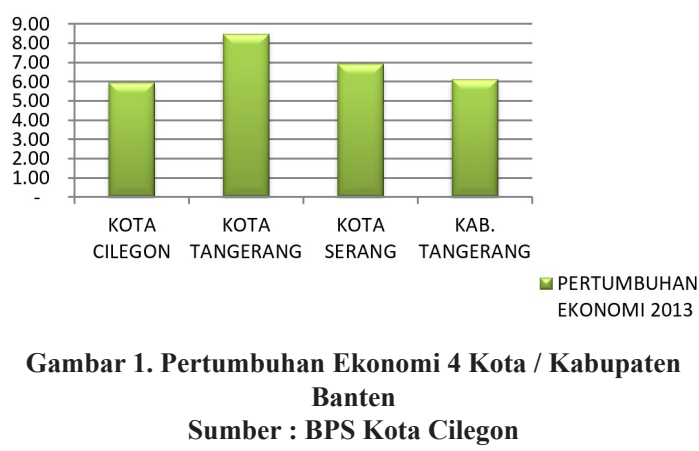

Pertumbuhan ekonomi Kota Cilegon tahun 2013 naik sebesar 5,93 persen tertinggi ke empat setelah Kota Tangerang $(8,48$ persen), Kota Serang (6,91 persen) dan Kabupaten Tangerang (6,11 persen) (Laporan Bank Indonesia (BI) soal properti komersial, 2012)

Informasi di atas dapat memberikan gambaran market share Hotel XYZ Banten tahun 2013 terhadap Hotel Berbintang di Kota Cilegon akan mengalami peningkatan pada kisaran 5,93\% dengan adanya pertumbuhan ekonomi Kota Cilegon dan bertambahnya Penanaman Modal Asing.

\section{INVESTASI PENANAMAN MODAL} ASING DI CILEGON

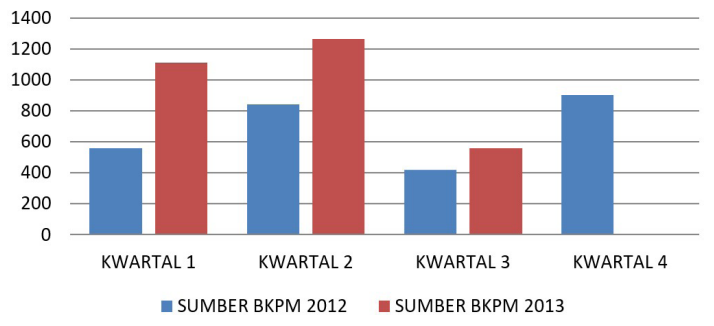

Data menurut BKPM terdapat kenaikan investasi penanaman modal asing di Cilegon pada Kwartal 1 tahun 2012 sebesar Rp. 555,8 Milyar mengalami kenaikan di tahun 2013 menjadi Rp.1.109 Milyar, Kwartal 2 tahun 2012 sebesar Rp. 842 Milyar mengalami kenaikan di tahun 2013 menjadi Rp. 1.264 Milyar, Kwartal 3 tahun 2012 sebesar Rp. 418,7 Milyar mengalami kenaikan di tahun 2013 menjadi Rp. 555 Milyar dan Kwartal 4 tahun 2012 sebesar Rp.899,8 Milyar.

Kelangsungan hidup sebuah hotel sangat tergantung dari apakah pendapatan tahunan dapat menutup pengeluaran tahunan. Pendapatan utama hotel berbeda antara hotel yang satu dengan hotel lainnya. Perbedaan pendapatan ini disebabkan oleh banyaknya variable dan besar rata-rata tiap variabel tersebut untuk digunakan untuk perencanaan investasi.

Berdasarkan uraian tersebut maka peneliti akan melakukan analisis lebih mendalam tentang sejauh mana investasi yang telah dilakukan memberikan kontribusi terhadap profitabilitas Hotel XYZ Banten 
yang akan diubah kapasitasnya menjadi bintang empat. Analisis lebih jauh akan menggunakan metode Break Event Point (BEP), Internal Rate of Return (IRR), Revenue Cost Ratio (RCR), Return On Investment (ROI), Tingkat Pengembalian Modal Sendiri (Return On Equity), Cost Benefit Ratio (CBR) dan Profitability Index.

Penelitian berfokus kepada analisis kelayakan pengembangan investasi Hotel XYZ yang telah dilakukan dalam mengantisipasi naiknya kebutuhan kamar hotel di Kota Cilegon terkait dengan berkembangnya industri dan banyak masuknya Investor asing sejak awal tahun 2012 (www.bi.go.id Kajian Ekonomi Regional Provinsi Banten 2013)

\section{TINJAUAN PUSTAKA}

\section{II.1. PENGERTIAN MANAJEMEN}

Secara etimologi kata manajemen berasal dari Bahasa Perancis Kuno management, yang berarti seni melaksanakan dan mengatur. Pengertian secara terminologi para pakar mendefinisikan manajemen secara beragam, diantaranya: Wijayanti (2008:1) menyebutkan menurut Follet manajemen sebagai seni dalam menyelesaikan pekerjaan melalui orang lain.

\section{II.2. FUNGSI-FUNGSI MANAJERIAL}

MenurutTerry(2010:9), fungsimanajemen dapat dibagi menjadi Empat bagian, yakni perencanaan (planning), pengorganisasian (organizing), pelaksanaan (actuating), dan pengawasan (controlling) :

\section{Perencanaan (Planning)}

Perencanaan (Planning) ialah penetapan pekerjaan yang harus dilaksanakan oleh kelompok untuk mencapai tujuan yang digariskan. Planning mencakup kegiatan pengambilan keputusan, karena termasuk dalam pemilihan alternatif-alternatif keputusan.

\section{Pengorganisasian (Organizing)}

Pengorganisasian dilakukan untuk menghimpun dan mengatur semua sumber-sumber yang diperlukan termasuk manusia, sehingga pekerjaan yang dikehendaki dapat dilaksanakan dengan berhasil.

\section{Pelaksanaan (Actuating)}

Pelaksanaan merupakan usaha menggerakkan anggota-anggota kelompok sedemikian rupa, hingga mereka berkeinginan dan berusaha untuk mencapai tujuan yang telah direncanakan bersama. Terry (1993:62).

\section{Pengawasan (Controlling)}

Pengawasan (controlling) adalah penemuan dan penerapan cara dan alat utk menjamin bahwa rencana telah dilaksanakan sesuai dengan rencana yang telah ditetapkan.

\section{II.3. PENGERTIAN MANAJEMEN KEUANGAN}

Manajemen keuangan merupakan manajemen terhadap fungsi-fungsi keuangan. Sutrisno (2009:5) menjelaskan fungsi-fungsi keuangan tersebut meliputi : (1) bagaimana memperoleh dana (raising of fund) (2) bagaimana menggunakan dana tersebut (allocation of fund). Manajer Keuangan berkepentingan dengan penentuan jumlah aktiva yang layak dari investasi pada berbagai aktiva dan pemilihan sumber-sumber dana untuk membelanjai aktiva tersebut.

Pengelolaan terhadap manajemen keuangan merupakan tugas dan tanggungjawab Manajer Keuangan. Tugas pokok manajemen keuangan antara lain meliputi :

1. Keputusan tentang investasi (investment decisions) 
2. Keputusan pembiayaan (financing decisions)

3. Pembagian dividen suatu perusahaan (dividend decisions).

Berdasarkan uraian tersebut di atas maka peneliti menyimpulkan bahwa manajemen keuangan merupakan pengelolaan keuangan yang dimulai dari perencanaan (perolehan sumber dana), pengorganisasian dana, penggunaan dana dan pengontrolan dana agar dana dapat digunakan seefisien mungkin dan tepat sasaran untuk melakukan investasi pengembangan perusahaan.

\section{II.4. FUNGSI DAN TUJUAN MANAJEMEN KEUANGAN}

Menurut Fahmi (2012:2) ilmu manajemen keuangan berfungsi sebagai pedoman bagi manajer perusahaan dalam setiap pengambilan keputusan yang dilakukan. Hal ini berarti seorang manajer keuangan boleh melakukan terobosan dan kreatifitas berfikir namun tetap menggunakan kaidah-kaidah yang berlaku dalam ilmu manajemen keuangan.

Ada beberapa tujuan dari manajemen keuangan menurut Fahmi (2012:2) yaitu :

1. Memaksimumkan nilai perusahaan.

2. Menjaga stabilitas finansial dalam keadaan yang selalu terkendali.

3. Memperkecil risiko perusahaan dimasa sekarang dan yang akan datang.

\section{II.5. PENGERTIAN BISNIS HOTEL}

Menurut Surat Keputusan Menteri Pariwisata, Pos dan Telekomunikasi No: KM 34/HK 103/MPPT-87. Hotel adalah suatu jenis akomodasi yang mempergunakan sebagian atau seluruh bangunan untuk menyediakan jasa pelayanan penginapan, makanan dan minuman serta jasa lainnya bagi umum, yang dikelola secara komersial serta memenuhi ketentuan persyaratan yang ditetapkan dalam keputusan pemerintah.

Kriteria klasifikasi hotel di Indonesia secara resmi dikeluarkan oleh Dirjen Pariwisata dengan SK: Kep-22/U/VI/78. Suratkeputusan ini hotel dengan klasifikasi berbintang dapat digolongkan menjadi lima kelas. Penggolongan ini disesuaikan dengan syarat-syarat tertentu yang harus dipenuhi, terutama berhubungan dengan persyaratan umum mengenai keadaan kamar suatu hotel.

Manajemen Hotel dalam melaksanakan tugas operasional harian dan pengambilan keputusan memerlukan data dan informasi keuangan. Keputusan operasional akan lebih bermutu bila didasarkan atas informasi yang baik. Manajer harus mampu memanfaatkan informasi keuangan untuk mengambil keputusan seperti pengendalian harga pokok makanan dan minuman agar sesuai standar yang ditentukan, mengendalikan biaya variabel produk agar tidak merugi, mengendalikan biaya agar sesuai anggaran dan merencanakan anggaran modal untuk menunjang keberhasilan operasional Hotel.

Tehnik mengelola dalam menetapkan tarif kamar oleh Manajer Hotel akan sangat berpengaruh terhadap tingkat penjualan dan mencapai laba yang diharapkan maupun yang telah dianggarkan Manajemen Hotel. 


\section{II.6. PENELITIAN TERDAHULU}

Tabel 1. Penelitian Sebelumnya

\begin{tabular}{|c|c|c|c|c|}
\hline No & Peneliti, Tahun & $\begin{array}{c}\text { Judul } \\
\text { Penelitian }\end{array}$ & $\begin{array}{l}\text { Variabel } \\
\text { Penelitian }\end{array}$ & Hasil Penelitian \\
\hline 1. & $\begin{array}{l}\text { Natalia Christanti dan Linda } \\
\text { Ariany Mahastanti, } 2011 \\
\text { Jurnal Manajemen Teori dan } \\
\text { Terapan | Tahun 4, No. } 3 \\
\text {, Desember 2011, halaman } 37- \\
51\end{array}$ & $\begin{array}{l}\text { Faktor-Faktor } \\
\text { Yang } \\
\text { Dipertimbangkan } \\
\text { Investor Dalam } \\
\text { Melakukan } \\
\text { Investasi }\end{array}$ & $\begin{array}{l}\text { Neutral } \\
\text { Information dan } \\
\text { Accounting } \\
\text { Information } \\
\text { masing-masing } \\
\text { memiliki } 6 \\
\text { indikator, Self } \\
\text { Image/Firm- } \\
\text { Image } \\
\text { Coincidence } \\
\text { memiliki } \quad 5 \\
\text { indikator, Classic } \\
\text { dan Social } \\
\text { Relevance ada } 4 \\
\text { indikator, } \\
\text { Advocate } \\
\text { Recommendation } \\
\text { terdapat } \\
\text { indikator, } \\
\text { Personal } \\
\text { Financial Need } \\
\text { memiliki } \\
5 \text { indikator. }\end{array}$ & $\begin{array}{l}\text { Faktor yang banyak } \\
\text { dipertimbangkan } \\
\text { investor dalam } \\
\text { melakukan investasi } \\
\text { adalah } \\
\text { Neutral Information, } \\
\text { Accounting } \\
\text { Information, dan } \\
\text { aspek demografi juga } \\
\text { mempengaruhi } \\
\text { keputusan investasi } \\
\text { investor. Jadi hasil } \\
\text { penelitian ini sejalan } \\
\text { dengan penelitian- } \\
\text { penelitian sebelumnya } \\
\text { yang dilakukan di } \\
\text { negara lain. Investor di } \\
\text { Indonesia dalam } \\
\text { melakukan investasi } \\
\text { berdasarkan Economic } \\
\text { Factor. }\end{array}$ \\
\hline 2. & $\begin{array}{l}\text { Agin Abduh Khaer dan } \\
\text { Christiono Utomo, JURNAL } \\
\text { TEKNIK ITS Vol. 1, No. 1, } \\
\text { (Sept. 2012) ISSN: 2301-9271, } \\
\text { halaman 93-96. }\end{array}$ & $\begin{array}{l}\text { Pengaruh Tingkat } \\
\text { Hunian pada } \\
\text { Keputusan } \\
\text { Investasi Proyek } \\
\text { Hotel Santika } \\
\text { Gubeng } \\
\text { Surabaya }\end{array}$ & $\begin{array}{l}\text { Net Present } \\
\text { Value, Interest } \\
\text { Rate of Return }\end{array}$ & 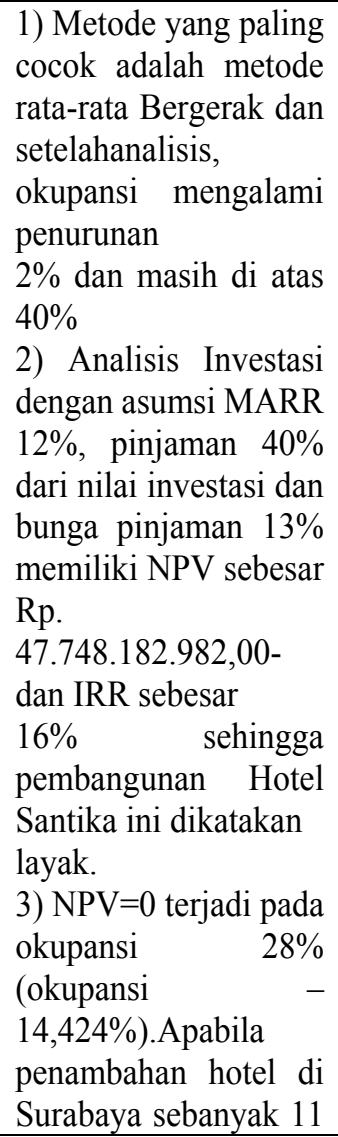 \\
\hline
\end{tabular}




\begin{tabular}{|c|c|c|c|c|}
\hline & & & & $\begin{array}{l}\text { hotel dilakukan, maka } \\
\text { okupansi hotel } \\
\text { menjadi } \\
11 \times 2 \%=22 \% \text {. Hal } \\
\text { ini memperlihatkan } \\
\text { bahwa. } \\
\text { penambahan hotel } \\
\text { sebanyak } 11 \text { hotel di } \\
\text { Surabaya tidak layak } \\
\text { karena pengurangan } \\
\text { okupansi hotel yang } \\
\text { lebih dari } \\
14,424 \% .\end{array}$ \\
\hline 3. & $\begin{array}{l}\text { Putra, C.Utomo, B.Nurcahyo, } \\
2013\end{array}$ & $\begin{array}{l}\text { Analisa } \\
\text { Pembiayaan } \\
\text { Investasi Proyek } \\
\text { Apartemen Kerta } \\
\text { Jaya }\end{array}$ & Net Present Value & $\begin{array}{l}\text { Pembiayaan efektif } \\
\text { dapat dibagi menjadi } \\
\text { empat jenis yaitu : } \\
\text { a. } 100 \% \text { Modal } \\
\text { sendiri } \\
\text { b. } 20 \% \text { sendiri dan } \\
80 \% \text { pinjaman } \\
\text { c. } 50 \% \text { sendiridan } \\
50 \% \text { pinajaman, } 80 \% \\
\text { sendiri dan } 20 \% \\
\text { pinajaman }\end{array}$ \\
\hline 4. & $\begin{array}{l}\text { Ofianto Wahyudhi dan } \\
\text { Christiono Utomo, } \\
\text { JURNAL TEKNIK POM ITS } \\
\text { Vol. 3, No. 1,(2014) } \\
\text { ISSN: } 2337 \\
\text {-3539 online, (2301- } 9271 \text { Print) } \\
\text { - Halaman } 41 \text { - } 46 .\end{array}$ & $\begin{array}{l}\text { Analisis Investasi } \\
\text { pada Proyek } \\
\text { Pembangunan } \\
\text { Apartemen Bale } \\
\text { Hinggil Surabaya }\end{array}$ & $\begin{array}{l}\text { Net Present } \\
\text { Value, Interest } \\
\text { Rate of Return }\end{array}$ & 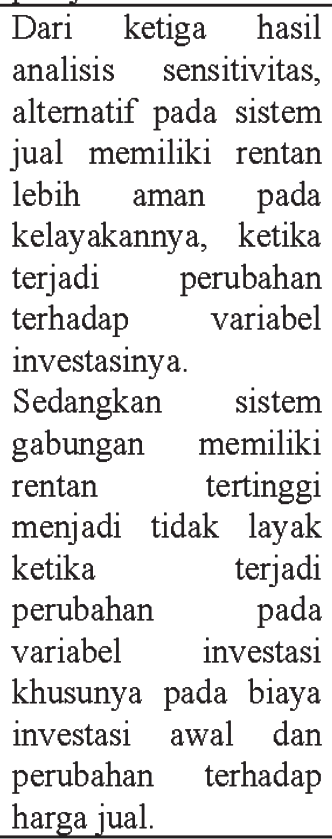 \\
\hline 5. & $\begin{array}{l}\text { Steven Fredrik Josef Manopo } \\
\text { J. Tjakra, R. J. M. Mandagi, M. } \\
\text { Sibi, Jurnal Sipil Statik Vol.1 } \\
\text { No.5, April 2013 (377-381) } \\
\text { ISSN: 2337-6732, Halaman 377 } \\
\text {-381 }\end{array}$ & $\begin{array}{l}\text { Analisis Biaya } \\
\text { Investasi Pada } \\
\text { Perumahan Griya } \\
\text { Paniki Indah }\end{array}$ & $\begin{array}{lr}\text { Net } & \text { Present } \\
\text { Value } & \text { (NPV), } \\
\text { Internal Rate of } \\
\text { Retum } & \text { (IRR), } \\
\text { Index Profibility } \\
\text { (IP), Payback } \\
\text { Period } & \text { (PP), } \\
\text { Break Even Point } \\
\text { (BEP). }\end{array}$ & $\begin{array}{l}\text { Net Present Value = } \\
\text { Rp. } 3.226 .683 .070 \\
\text { yang memberikan } \\
\text { nilai positif. Internal } \\
\text { Rate of Return } \\
\text { memberikan niai lebih } \\
\text { besar dari i yang } \\
\text { direncanakan yaitu } \\
\text { sebesar 10.609\%. } \\
\text { Index Profibility } \\
\text { memberikan nilai }\end{array}$ \\
\hline
\end{tabular}




\begin{tabular}{|c|c|c|c|c|}
\hline & & & & $\begin{array}{l}\text { yang lebih besar dari } \\
\text { I (IP> } 1 \text { yaitu } 1,183 . \\
\text { Payback Period (PP) } \\
\text { akan kembali pada } \\
\text { tahunke-7bulanke-10 } \\
\text { hari ke-13. Break } \\
\text { Even Point = Rp. } \\
\text { 1.065.498.573. } \\
\text { Dengan demikian } \\
\text { perumahan Griya } \\
\text { Paniki Indah } \\
\text { memenuhi syarat } \\
\text { dalam kriteria } \\
\text { investasi sehingga } \\
\text { investasi pada proyek } \\
\text { ini menguntungkan } \\
\text { dan baik untuk } \\
\text { dilaksanakan } \\
\text { Penyusunanans dana } \\
\text { (cash flow) sangat } \\
\text { menentukan dalam } \\
\text { menganalisis biaya } \\
\text { investasi, untuk itu } \\
\text { diharapkan ketelitian } \\
\text { dalam mengestimasi } \\
\text { pendapatan dan biaya } \\
\text { proyek. }\end{array}$ \\
\hline 6. & $\begin{array}{l}\text { Ficka Andria Pratama, Herry } \\
\text { Boesono, dan Trisnani Dwi H, } \\
\text { Journal of Fisheries Resources } \\
\text { Utilization Management and } \\
\text { Technology Volume 1, Nomor } 1 \text {, } \\
\text { Tahun } 2012 \text {, Hlm 22-31 Online } \\
\text { di: http://www.ejournal- } \\
\text { sl.undip.ac.id/index.php/frumt }\end{array}$ & $\begin{array}{l}\text { Analisis } \\
\text { Kelayakan } \\
\text { Finansial Usaha } \\
\text { Penangkapan } \\
\text { Ikan } \\
\text { Menggunakan } \\
\text { Panah Dan Bubu } \\
\text { Dasar Di Perairan } \\
\text { Karimunjawa }\end{array}$ & $\begin{array}{l}\text { NPV, IRR, B/C } \\
\text { Ratio, ROI, } \\
\text { Payback Peniod } \\
\text { dan Profitabilitas } \\
\text { Indeks }\end{array}$ & 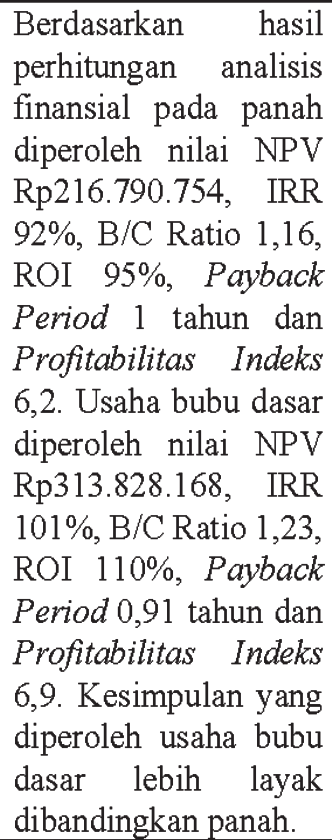 \\
\hline
\end{tabular}


Beberapa pendekatan yang digunakan dalam melakukan analisis investasi bidang perhotelan ini meliputi :

\section{Profitability Indeks (PI)}

Metode Profitability Indeks adalah menghitung melalui perbandingan antara nilai sekarang (present value) dari rencana-rencana penerimaan khas bersih dimasa yang akan datang dengan nilai sekarang (present value) dari investasi yang telah dilaksanakan. Keuntungan menggunakan metode ini adalah:

1. Memperhitungkan nilai waktu dari pada uang (time value of money)

2. Menetukan terlebih dahulu tingkat bunga yang akan digunakan.

\section{Metode Nilai Sekarang Netto (Net Present Value)}

Metode ini dikenal sebagai metoda Present Worth (Nilai Sekarang) dan digunakan untuk menentukan apakah suatu rencana mempunyai keuntungan dalam periode waktu analisis. Hal ini dihitung dari Present Worth af the Revenue (PWR), dan Present Worth of the Cost (PWC). Aliran kas proyek yang dikaji meliputi keseluruhan, yaitu biaya modal, operasional, produksi, pemeliharaan,dan pengeluaran lain - lain.

$\mathrm{NPV}=\mathrm{PWR}-\mathrm{PWC}$

$\mathrm{NPV}=$ nilai sekarang netto

PWR = nilai sekarang dari pendapatan

PWC = nilai sekarang dari biaya / pengeluaran

Kriteria keputusan untuk mengetahui layak atau tidaknya suatu investasi dalam metode NPV, yaitu jika :

NPV $>0$, usulan investasi diterima (menguntungkan)
NPV $<0$, usulan invesiasi ditolak (tidak menguntungkan)

$\mathrm{NPV}=0$, nilai investasi sama walau usulan investasi diterima maupun ditolak

\section{Metode Revenue Cost Ratio (RCR)}

Metode ini menganalisis suatu proyek dengan membandingkan nilai revenue terhadap nilai cost. Rumus untuk menghitung RCR adalah :

$$
\mathrm{RCR}=\frac{\mathrm{PWR}}{\mathrm{PWC}}
$$

Ada tiga kemungkinan nilai $\mathrm{R} / \mathrm{C}$ yang terjadi, yaitu:

1. Bila nilai $\mathrm{R} / \mathrm{C}<1$, proyek tidak layak dijalankan

2. Bila nilai $\mathrm{R} / \mathrm{C}=1$, proyek marginal (marginal project)

3. Bila nilai $\mathrm{R} / \mathrm{C}>\mathrm{I}$, proyek layak dijalankan

\section{Metode Arus Pengembalian Internal (Internal Rate of Return)}

Metode Tingkat Pengembalian/Internal Rate of Return Method (IRR) menurut Robert J. Kodoatie (1994) adalah besarnya tingkat bunga yang menjadikan biaya pengeluaran dan pemasukan sama besarnya. Logika sederhananya menjelaskan bahwa investasi dikatakan menguntungkan jika tingkat bunga ini lebih besar dari tingkat bunga yang relevan. Metoda ini digunakan untuk memperoleh suatu tingkat bunga dimana nilai pengeluaran sekarang bersih (NPV) adalah nol.

$\begin{array}{lll}\operatorname{NPV}(0)= & \text { PWR-PWC-I pada } \mathrm{i}=? \\ \mathrm{NPV} & =\quad \begin{array}{l}\text { nilai sekarang netto } \\ \text { PWR }=\end{array} & \begin{array}{l}\text { nilai sekarang dari } \\ \text { pendapatan }\end{array}\end{array}$



PWC $=$ nilai sekarang dari biaya/ pengeluaran
I $=$ biaya investasi setelah konstruksi.

Kriteria keputusan untuk mengetahui layak atau tidaknya suatu investasi dalam metode IRR jika :

IRR $>$ MARR (Minimum Attractive Rate of Return), usulan investasi diterima.

MARR (Minimum Attractive Rate of Return) merupakan tingkat pengembalian minimum yang diinginkan oleh investor. Dalam menentukan ini MARR, ada tiga hal yang paling sering dipertimbangkan, antara lain:

\section{Biaya peminjaman uang}

2. Biaya modal, merupakan biaya gabungan dari keseluruhan komponen - komponen modal perusahaan.

3. Opportunity cost, menunjukan biaya kesempatan yang hilang atau tingkat pengembalian yang didapatkan dari proyek investasi terbaik yang pernah ditolak.

Nilai MARR seharusnya sama besar dengan nilai tertinggi dari ketiga nilai diatas. Proyek dianggap layak jika nilai IRR lebih besar dari nilai MARR. Demikian pula sebaliknya proyek dianggap tidak layak untuk dilaksanakan jika nilai IRR yang dihasilkan proyek tersebut lebih kecil dari nilai MARR yang diharapkan investor.

\section{Tingkat Pengembalian Investasi (ROI)}

Pengembalian tingkat investasi return on investmen (ROI) dibedakan antara ROI sebelum pajak (ROI before tax) dan ROI setelah pajak (ROI after tax). (Jimmy.S Juwana, 2005) a). Return On Investment (ROI) sebelum Pajak :

Sebelum pinjaman lunas, yaitu tahun 1 sampai tahun ke 10

Laba sebelum pajak ditambah depresiasi :

$\mathrm{Lb}=$ pendapatan - biaya bunga pinjaman - biaya operasional - biaya asuransi.

Laba setelah pajak ditambah depresiasi :

$\mathrm{La}=$ Pendapatan - biaya operasioanal biaya asuransi - pajak

\section{Metode Rasio Biaya Manfaat (Cost Benefit Analysis)}

Metode ini memperhitungkan biaya serta manfaat yang akan diperoleh dari pelaksanaan suatu program. Dalam analisis manfaat (benefit) dan biaya (cost) perhitungan manfaat serta biaya ini merupakan satu kesatuan yang tidak dapat dipisahkan. Metode ini mempunyai banyak bidang penerapan. Salah satu bidang penerapan yang umum menggunakan rasio ini adalah dalam bidang investasi. Metode ini mempunyai penekanan dalam perhitungan tingkat keuntungan/ kerugian suatu program atau suatu rencana dengan mempertimbangkan biaya yang akan dikeluarkan serta manfaat yang akan dicapai.

Penerapan analisis ini banyak digunakan oleh para investor dalam upaya mengembangkan bisnisnya. Terkait dengan hal ini maka analisis manfaat dan biaya dalam pengembangan investasi hanya didasarkan pada rasio tingkat keuntungan dan biaya yang akan dikeluarkan atau dalam kata lain penekanan yang digunakan adalah pada rasio keuangan (financial).

Analisis biaya manfaat (Cost Benefit Analysis), kadang-kadang disebut analisis manfaat biaya (Cost Benefit Analysis), adalah proses sistematis untuk menghitung 
dan membandingkan manfaat dan biaya dari proyek untuk dua tujuan:

1. Untuk menentukan apakah itu adalah investasi yang sehat (pembenaran/ kelayakan).

2. Untuk melihat bagaimana membandingkan dengan proyekproyek alternatif (peringkat/ prioritas tugas). Ini melibatkan membandingkan biaya total diharapkan setiap pilihan terhadap manfaat yang diharapkan total, untuk melihat apakah manfaatnya lebih besar daripada biaya, dan seberapa banyak.

Metode-metode untuk menganalisis manfaat dan biaya suatu proyek yaitu Metode payback period (PP), Metode Present Value (NPV), Internal Rate of Return (IRR) dan perbandingan manfaat biaya (cost benefit ratio).

Metode menghitung perbandingan antara manfaat (benefit) terhadap biaya (cost) dalam suatu proyek investasi. Pada proyek-proyek swasta, keuntungan (benefit) umumnya berupa pandapatan minus diluar biaya pertama. Misalnya untuk operasi dan produksi sedangkan biaya (cost) adalah biaya pertama. Adapun rumus yang digunakan adalah:

$$
\begin{aligned}
\mathrm{BCR}= & \frac{\mathrm{PWC}}{\mathrm{PWB}} \\
\mathrm{BCR}= & \begin{array}{l}
\text { perbandingan manfaat terhadap } \\
\text { biaya (benefit cost ratio) }
\end{array} \\
\mathrm{PWB}= & \begin{array}{l}
\text { Present Worth of Benefit atau } \\
\text { nilai sekarang benefit }
\end{array} \\
\mathrm{PWC}= & \text { Present Worth of Cost. }
\end{aligned}
$$

\section{METODOLOGI PENELITIAN}

Sampel dalam penelitian ini adalah Hotel XYZ Cilegon di Provinsi Banten. Metode analisis untuk mengukur besaran pendapatan (income), biaya variabel operasional (operational variable cost), biaya langsung operasional (operational fixed cost), biaya pemasaran (marketing cost) serta keuntungan sebelum pajak (nett profit before tax) yang digunakan untuk menganalisis Laporan Keuangan selama 3 tahun terakhir, sedangkan untuk analisis pendapatan - pengeluaran (revenue - cost ratio). Metode yang dilakukan berupa metode kualitatif (wawancara, sampling dan observasi) di Hotel XYZ Banten.

\section{III.1. PARAMETER PENELITIAN}

Metode yang akan dijadikan parameter kelayakan sebuah investasi Hotel meliputi

1. Net Present Value (NPV),

2. Break Event Point (BEP)

3. Internal Rate of Return (IRR),

4. Revenue Cost Ratio (RCR),

5. Return On Investment (ROI),

6. Tingkat pengembalian modal sendiri (Return On Equity).

7. Benefit Cost Ratio (CBR)

8. Profitability Index (PI) 
Tabel 2. Variabel dan Parameter

\begin{tabular}{|c|c|c|}
\hline Variabel & Parameter & Difinisi \\
\hline $\begin{array}{l}\text { Kelayakan Investasi } \\
\text { Hotel }\end{array}$ & $\begin{array}{l}\text { a. Net Present Value } \\
\text { (NPV), }\end{array}$ & $\begin{array}{l}\text { Net Present Value selisih } \\
\text { antara Present Valtie } \\
\text { dari investasi dengan nilai } \\
\text { sekarang dari penerimaan } \\
\text { kas bersih (aliran kas } \\
\text { operasional maupun } \\
\text { aliran kas terminal) } \\
\text { dimasa yang akan datang. } \\
\text { Untuk } \\
\text { menghitung nilai sekarang } \\
\text { perlu ditentukan tingkat } \\
\text { bunga yang relevan } \\
\text { (Umar, 2000). } \\
\text { Kriteria Penilaian : } \\
\text { Jika NPV >0, maka usulan } \\
\text { proyek diterima } \\
\text { Jika NPV < 0, maka usulan } \\
\text { proyek ditolak } \\
\text { Jika NPV = 0, maka nilai } \\
\text { perusahaan tetap walau } \\
\text { usulan proyek diterima } \\
\text { ataupun ditolak. }\end{array}$ \\
\hline & $\begin{array}{l}\text { b. Revenue Cost } \\
\text { Ratio(RCR) }\end{array}$ & $\begin{array}{l}\text { RCR adalah perbandingan } \\
\text { antara penerimaan total } \\
\text { (TR - total revenue) dan } \\
\text { biaya total (TC- total } \\
\text { cost). RCR dapat disingkat } \\
\mathrm{R} / \mathrm{C} \text { digunakan untuk } \\
\text { mengetahui imbangan } \\
\text { penerimaan dengan biaya } \\
\text { dari usaha yang dilakukan. } \\
\text { Rumusan imbangan } \\
\text { penerimaan dan biaya } \\
\text { (Pambudhi, } 2008: 78 \text { ) }\end{array}$ \\
\hline
\end{tabular}




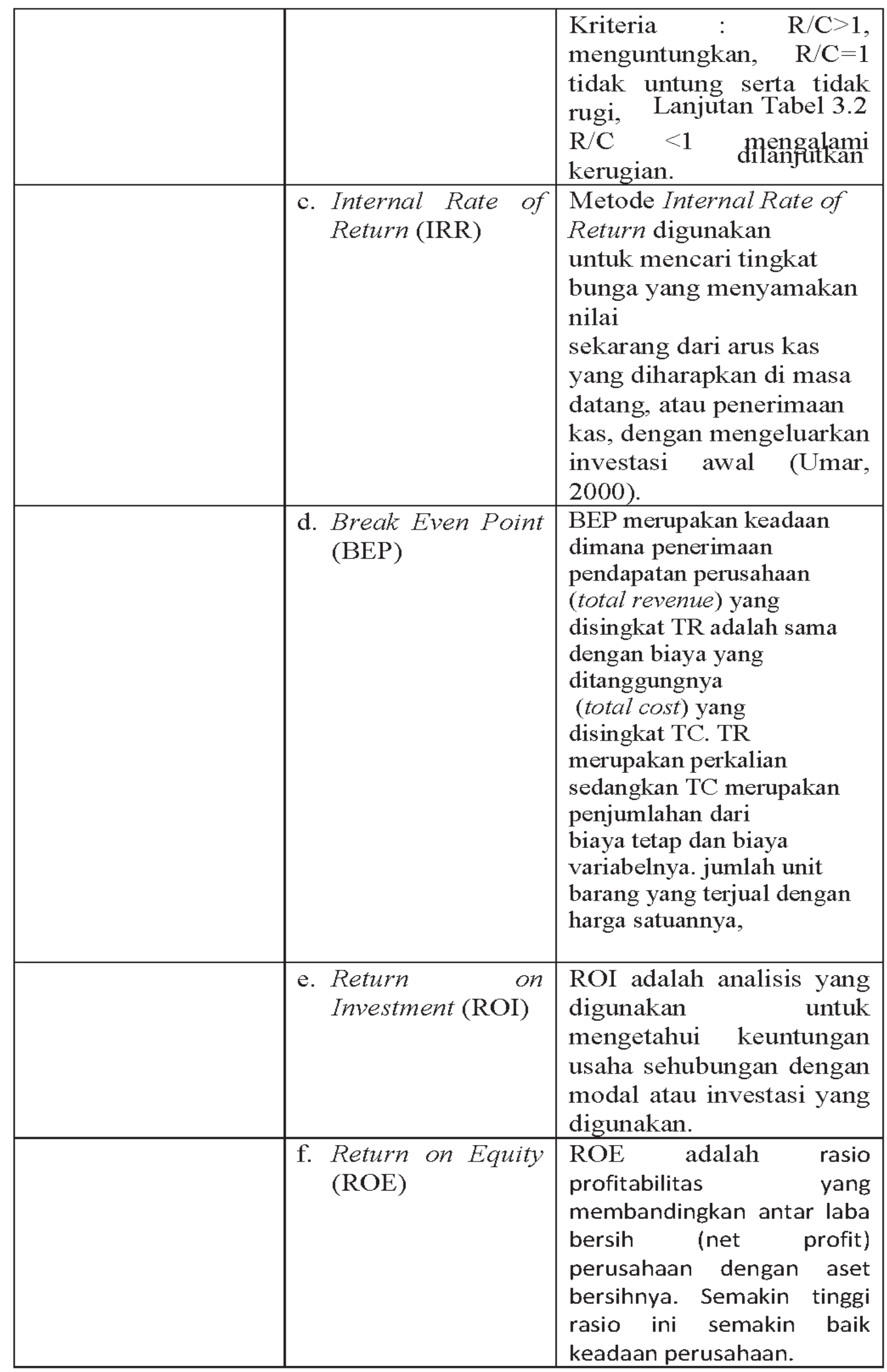


Sebagai pelengkap metode penelitian, penggunaan analisis sensitifitas diterapkan dengan variabel Tingkat Penghuni Kamar (TPK), suka bunga (i), dan Investasi Total (I). Variabel di atas akan mengalami perubahan sebesar $-30 \%$ hingga $+30 \%$ dari nilai awal, kemudian dilakukan pengamatan terhadap parameter pengukur yang ada. Jika suatu perubahan kecil variabel dapat merubah secara drastis nilai parameter pengukur kelayakan maka dikatakan variabel tersebut sangat sensitif terhadap parameter. Berbanding sebaliknya, jika perubahan drastis pada variabel hanya berpengaruh sedikit pada parameter kelayakan maka dikatakan variabel tersebut relatif insensitif.

\section{III.2. TEKNIK PENGUMPULAN DATA}

Pengumpulan data sekunder diperoleh dengan cara mengadakan wawancara langsung, observasi dan sampling di Hotel "XYZ", PHRI Provinsi Banten, Dinas Budaya dan Dinas Budaya dan Pariwisata Kota Cilegon.

\section{HASIL DAN PEMBAHASAN IV.1. LAPORAN KEUANGAN HOTEL XYZ}

Tabel 3. Neraca XYZ hotel

\begin{tabular}{|c|c|c|c|}
\hline $\begin{array}{c}\text { Keterangan } \\
\text { Tahun }\end{array}$ & $31 / 12 / 12$ & $31 / 12 / 13$ & $31 / 12 / 14$ \\
\hline Aktiva Lancar & $34,012,002,478$ & $45,262,443,747$ & $32,328,110,001$ \\
\hline Aktiva Tetap & $83,774,181,839$ & $80,794,907,435$ & $78,748,290,552$ \\
\hline & & & \\
\hline Kewajiban Lancar & $13,185,448,942$ & $16,453,225,317$ & $13,496,344,415$ \\
\hline $\begin{array}{c}\text { Kewajiban Jangka } \\
\text { Panjang }\end{array}$ & - & $21,249,690,298$ & $12,711,095,300$ \\
\hline Modal (Equity) & $101,552,065,316$ & $78,453,438,759$ & $63,405,655,703$ \\
\hline & & $10,058,830,136$ & $8,756,514,973$ \\
\hline PR0FIT & $3,560,728,304$ & $12,11,198,983,878$ \\
\hline Total Asset & $118,333,929,162$ & $126,215,184,511$ & 111,5 \\
\hline
\end{tabular}

Catatan : Penulis hanya mendapatkan Laporan Laba (Rugi) 2 tahun terakhir
Tabel 4. Laporan Laba (rugi) XYZ Hotel

\begin{tabular}{|l|c|c|}
\hline \multicolumn{1}{|c|}{ Keterangan / Tahun } & $\mathbf{3 1 / 1 2 / 1 3}$ & $\mathbf{3 1 / 1 2 / 1 4}$ \\
\hline Pendapatan & $5,176,678,833$ & $5,593,566,055$ \\
\hline Pendapatan Pihak Ketiga & $51,553,339,982$ & $49,777,195,605$ \\
\hline Total Pendapatan & $56,730,018,815$ & $55,370,761,660$ \\
\hline Biaya Variabel & $24,956,954,242$ & $22,310,347,105$ \\
\hline Biaya tetap lansung & $13,330,119,122$ & $14,287,750,634$ \\
\hline Biaya Administrasi \& Umum & $5,900,651,185$ & $6,528,759,015$ \\
\hline Biaya Pemasaran & $1,640,966,868$ & $1,787,351,087$ \\
\hline Total Biaya & $45,828,691,417$ & $44,914,207,841$ \\
\hline Pendapatan lain-lain & $\mathbf{2 , 4 2 5 , 9 8 5 , 5 8 4}$ & $1,778,871,917$ \\
\hline Laba (Rugi) Bersih & $\mathbf{1 0 , 0 5 8 , 8 3 0 , 1 3 7}$ & $\mathbf{8 , 7 5 6 , 5 1 4 , 9 7 5}$ \\
\hline
\end{tabular}

\section{IV.2. KENAIKAN KEUNTUNGAN (PROFIT)}

Laporan Keuangan XYZ Hotel 20122014 diperoleh data bahwa penambahan pembangunan Tower Hotel dan Restaurant "Golf View" sebesar Rp. 60 milyar mendapat dukungan dana dari Hutang Bank sebesar Rp. 7.617.760.000 (Jangka Pendek) tahun 2013 dan penambahan sebesar Rp. 1.001.210.000 tahun 2014 dan Rp. 21.241.731.967 (Jangka Panjang) tahun 2013.

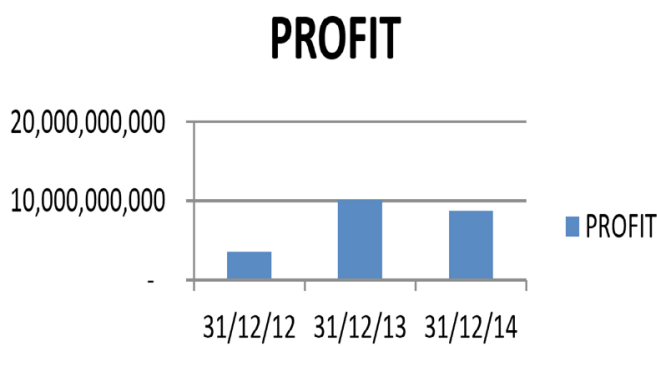

Gambar 2. Keuntungan (Profit) XYZ Hotel

Penambahan jumlah kamar dan restaurant memberikan kontribusi kenaikan laba bersih Hotel XYZ tahun 2013 sebesar Rp. 6.498.101.832 setara dengan kenaikan $182,5 \%$ dari laba bersih tahun 2012. Terlihat di Laporan Keuangan bahwa terjadi sedikit penurunan laba bersih di tahun 2014 sebesar Rp. 1.302.315.163 setara dengan penurunan $12,95 \%$ dari laba bersih tahun 2013 . 


\section{IV.3. ANALISA PENGARUH INVESTASI HOTEL}

\section{IV.3.1 KENAIKAN TINGKAT HUNIAN KAMAR}

Analisis atas Laporan Keuangan tahun 2012 - 2014 memperlihatkan adanya peningkatan tingkat hunian 105.193 kamar tahun 2013 dan 114.496 kamar tahun 2014.

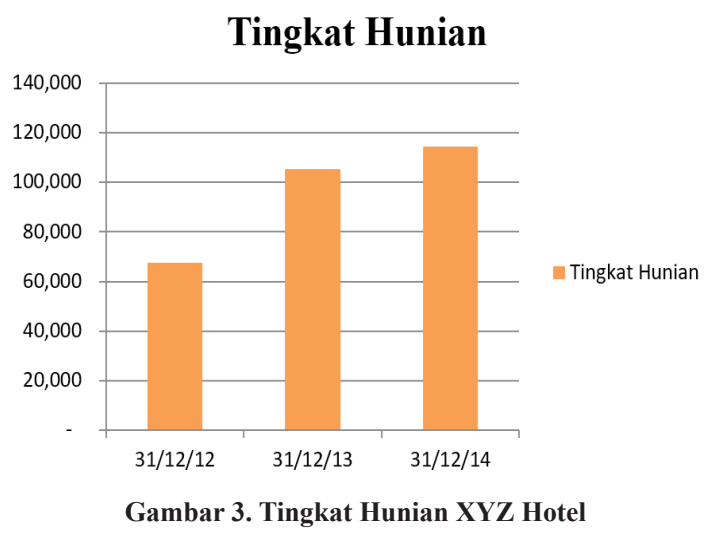

IV.3.2. PERUBAHAN TARIF SEWA

\section{KAMAR}

Analisis atas Laporan Keuangan tahun 2012 - 2014 memperlihatkan adanya perubahan kenaikan rata-rata tarif sewa kamar Rp. 525.000 tahun 2012, Rp. 637.519 dan tahun 2013, Rp. 756.689,--

Rata-rata Tarif Sewa Kamar

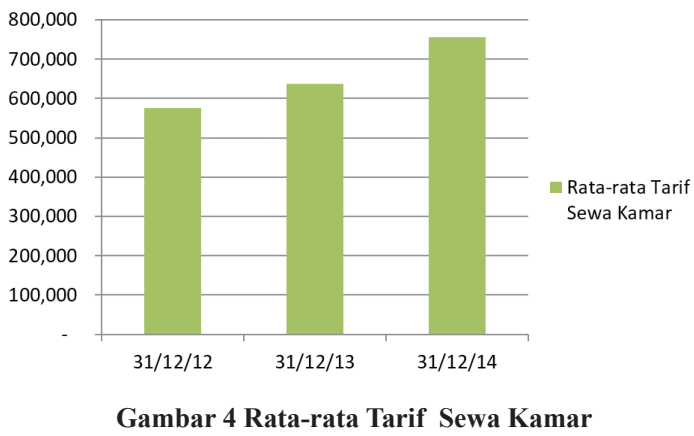

Hasil analisis dari Laporan Keuangan 3 tahun terakhir terlihat bahwa Hotel XYZ menerapkan tarif dengan tarif pesaing dan kemudian melakukan diferensiasi pada faktor-faktor seperti: lokasi, suasana, dan faktor non tarif lainnya. Tarif pesaing ini cenderung akan menjamin tidak adanya rate-cutting yang menyebabkan penurunan laba dengan kata lain terdapat stabilitas pasar.

\section{IV.3.3. KENAIKAN PENDAPATAN (REVENUE)}

Analisis atas Laporan Keuangan tahun 2012-2014 memperlihatkan adanya peningkatan tingkat hunian dan perubahan naiknya rata-rata tarif sewa kamar berakibat secara otomatis terdapat kenaikan pendapatan (revenue).

Tabel 5. Pendapatan Hotel XYZ

\begin{tabular}{|c|c|c|c|}
\hline TAHUN & $31 / 12 / 12$ & $31 / 12 / 13$ & $31 / 12 / 14$ \\
\hline $\begin{array}{l}\text { Pendapatan } \\
\text { (revenue) }\end{array}$ & $24,681,300,000$ & $59,156,004,399$ & $57,149,633,577$ \\
\hline
\end{tabular}

Kenaikan pendapatan (revenue) tahun 2013 sebesar Rp. 34,47 milyar (139,68 \%) dan tahun 2014 kenaikan sebear Rp. (131,55 \%) dibandingkan periode Laporan Keuangan tahun 2012.

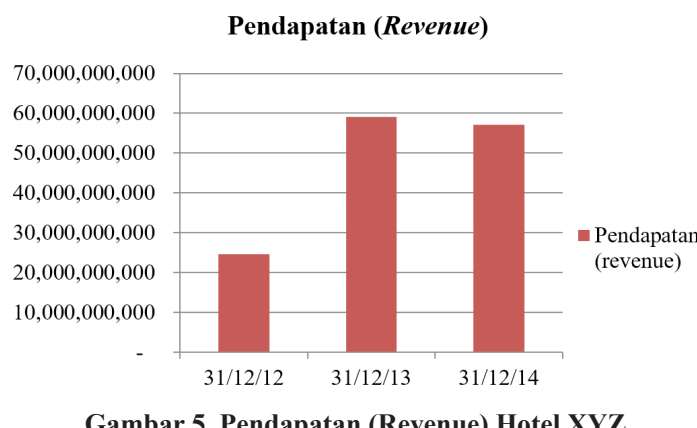

\section{IV.3.4. KENAIKAN KEMAMPUAN PENGEMBALIAN INVESTASI}

Analisis atas Laporan Keuangan tahun 2012 - 2014 memperlihatkan adanya peningkatan tingkat hunian dan perubahan naiknya rata-rata tarif sewa kamar berakibat secara otomatis terdapat kenaikan pendapatan (revenue) yang menjadikan adanya peningkatan kemampuan pengembalian investasi diatas kenaikan suku bunga pinjaman Bank. Hal ini dapat terlihat di Laporan Keuangan bahwa Pihak Hotel XYZ telah melakukan pengembalian Hutang Jangka Panjang nya sebesar Rp. 8,53 milyar (40,18\%) di tahun 2014. 


\section{IV.3.5. PERHITUNGAN RASIO INVESTASI HOTEL}

Berdasarkan analisis Laporan keuangan Hotel XYZ tahun 2012-2014 dapat dilakukan perhitungan dengan beberapa pendekatan metode dan rasio investasi.

\section{Perhitungan Net Present Value (NPV)}

NetPresent Value(NPV)banyak digunakan dalam melakukan analisis keuangan khususnya untuk mengidentifikasi apakah suatu rencana investasi yang dilakukan memberikan dampak keuntungan dalam periode waktu analisis. Hal ini dihitung dari Present Worth of the Revenue (PWR), dan Present Worth of the Cost (PWC).

$\mathrm{NPV}=\sum \mathrm{AT} /(1+\mathrm{k}) 1$

Investasi Pembangunan Tower dan restaurant sebesar Rp. 60 milyar

Perhitungan NPV :

Waktu 8 tahun (estimasi pengembalian investasi)

Tingkat bunga (interest rate) sebesar 12\%

Pendapatan (revenue) yang diharapkan sebesar Rp. 20 milyar setiap tahun.

PV dari proceeds : 4,968 x Rp 20.000.000.000

$$
\text { = Rp. 99, } 36 \text { Milyar }
$$

PV dari outlays : Rp. 60 milyar (invetasi Hotel).

NPV

$$
\begin{aligned}
\text { : } & \text { Rp. 99,36 Milyar - } \\
& \text { Rp. } 60 \text { Milyar } \\
= & \text { Rp. } 39,36 \text { milyar }
\end{aligned}
$$

NPV $>0$ maka investasi dengan NPV Rp. 39,36 milyar dapat dilanjutkan / diterima

\section{Break Event Point (BEP)}

Tabel 6. Analisis BEP Hotel XYZ

\begin{tabular}{|l|c|c|c|}
\hline TAHUN & $31 / 12 / 12$ & $31 / 12 / 13$ & $31 / 12 / 14$ \\
\hline PROFIT & $3,560,728,304$ & $10,058,830,136$ & $8,756,514,973$ \\
\hline \% Kenaikan / tahun & $182.5 \%$ & $145.9 \%$ \\
\hline \multicolumn{3}{|l|}{ Total 3 thn Keuntungan } & $22,376,073,413$ \\
\hline \multicolumn{3}{|l|}{ Rata-rata Keuntungan / tahun } & $7,458,691,138$ \\
\hline
\end{tabular}

Berdasarkan Analisis Laporan Keuangan Hotel XYZ tahun 2012-2014 dengan melakukan pendekatan Break Event Point (BEP) maka Hotel XYZ dapat melakukan pengembalian investasinya selama :

Investasi yang telah dilakukan

Rp. 60.000 .000 .000

Rata-rata keuntungan / tahun

Rp. 7.458.691.138

\section{$B E P=8$ TAHUN 16 HARI}

Hotel XYZ telah melakukan pengembalian $40 \%$ dari pinjaman jangka panjangnya di Bank sebesar Rp. 8,53 milyar (14,23\%) di tahun 2014 lebih banyak dari seharusnya hanya Rp, 12,5 milyar (12,5\%). Kondisi ini menjelaskan bahwa Hotel XYZ mampu mengembalikan investasinya lebih cepat dari perhitungan BEP (Break Event Point).

\section{Perhitungan Internal Rate of Return (IRR)}

Tabel 7. Analisis IRR Hotel XYZ

\begin{tabular}{|l|c|c|c|c|}
\hline TAHUN & $31 / 12 / 12$ & $31 / 12 / 13$ & $31 / 12 / 14$ & $\begin{array}{c}\text { RATA- } \\
\text { RATA }\end{array}$ \\
\hline REVENUE & $24,681,300,000$ & $59,156,004,399$ & $7,149,633,577$ & $46,995,645,992$ \\
\hline COST & $21,12,571,696$ & $49,097,174,262$ & $48,393,118,602$ & $39,536,954,853$ \\
\hline \multicolumn{2}{r}{} & & IRR & $15,87 \%$ \\
\cline { 5 - 6 } & &
\end{tabular}

Metode Internal Rate of Return (IRR) digunakan untuk menganalisis besarnya tingkat bunga yang menjadikan biaya pengeluaran dan pemasukan sama besarnya IRR Hotel XYZ 15,87 \% > 8,5\% (interest deposit bank) dimana IRR $>\mathrm{i}$ (suku bunga), sehingga usulan investasi 
diterima.

\section{Metode Revenue Cost Rasio (RCR)}

Tabel 8. Analisis RCR Hotel XYZ

\begin{tabular}{|c|c|c|c|}
\hline TAHUN & $\mathbf{3 1 / 1 2 / 1 2}$ & $\mathbf{3 1 / 1 2 / 1 3}$ & $\mathbf{3 1} / \mathbf{1 2} / \mathbf{1 4}$ \\
\hline REVENUE & $24,681,300,000$ & $59,156,004,399$ & $57,149,633,577$ \\
\hline COST & $21,120,571,696$ & $49,097,174,262$ & $48,393,118,602$ \\
\hline RCR & $\mathbf{1 . 1 7}$ & $\mathbf{1 . 2 0}$ & $\mathbf{1 . 1 8}$ \\
\hline
\end{tabular}

Analisis laporan keuangan Hotel XYZ mengenai RCR (Revenue Cost Rasio) sebesar 1,17 pada tahun 2012, sebesar 1,20 pada tahun 2013 dan sebesar 1,38 tahun 2014 yang menjelaskan bahwa $\mathrm{R} /$ $\mathrm{C}>1$ menguntungkan setelah proyek pembangunan Tower Hotel dan Restaurant dilaksanakan.

\section{Metode Return on Investment (ROI)}

Tabel 9. Analisis ROI Hotel XYZ

\begin{tabular}{|c|c|c|c|}
\hline Profit (Loss) & $3,560,728,304$ & $10,058,830,136$ & $8,756,514,973$ \\
\hline Total Investasi & $60,000,000,000$ & $64,289,438,374$ & $69,089,398,904$ \\
\hline $\begin{array}{c}\text { R0I } \\
\text { (Return On Investment) }\end{array}$ & $\mathbf{5 . 9 3 \%}$ & $\mathbf{1 5 . 6 5 \%}$ & $\mathbf{1 2 . 6 7 \%}$ \\
\hline
\end{tabular}

Analisis laporan keuangan Hotel XYZ mengenai ROI (Return on Investment) sebesar 5,93\% tahun 2012 dan 15,65\% tahun 2013 serta $12,67 \%$ tahun 2014 yang menjelaskan bahwa terjadi peningkatan kemampuan Hotel XYZ dalam memperoleh laba operasi dari modal yang diinvestasikan dalam keseluruhan aktiva setelah proyek pembangunan Tower Hotel dan Restaurant dilaksanakan.

\section{Metode Return on Equity (ROE)}

Tabel 9. Analisis ROE Hotel XYZ

\begin{tabular}{|l|c|c|c|}
\hline Profit (Loss) & $3,560,728,304$ & $10,058,830,136$ & $8,756,514,973$ \\
\hline Owner Equity & $101,552,065,316$ & $78,453,438,759$ & $63,405,655,703$ \\
\hline $\begin{array}{l}\text { R0E } \\
\text { (Return On Equity) }\end{array}$ & $\mathbf{3 . 5 1 \%}$ & $\mathbf{1 2 . 8 2 \%}$ & $\mathbf{1 3 . 8 1 \%}$ \\
\hline
\end{tabular}

Analisis laporan keuangan Hotel XYZ mengenai ROE (Return on Equity) sebesar $3,51 \%$ tahun 2012 dan $12,82 \%$ tahun 2013 serta $13,81 \%$ tahun 2014 yang menjelaskan bahwa terjadi peningkatan kemampuan

Hotel XYZ dalam memperoleh laba bersih dari modal yang disetor setelah proyek pembangunan Tower Hotel dan Restaurant dilaksanakan.

\section{Cost Benefit Ratio (CBR)}

Waktu 8 tahun (estimasi pengembalian investasi). Tingkat bunga (interest rate) sebesar 12\% Pendapatan (revenue) yang diharapkan sebesar Rp. 20 milyar setiap tahun.

PV dari proceeds : 4,968 $\quad$ $\quad \mathrm{Rp}$ 20.000.000.000=Rp. 99, 36 Milyar

PV dari outlays $\quad=$ Rp. 60 milyar (Investasi Hotel)

CBR

$$
\begin{aligned}
= & \text { PV Proceed }: \\
& \text { PV outlay } \\
= & 1,65
\end{aligned}
$$

CBR $>1$ maka pembangunan Tower Hotel dan Restaurant "Golf View" dapat diterima / dilanjutkan.

\section{Profitabilty Index (PI)}

Waktu 8 tahun (estimasi pengembalian investasi). Tingkat bunga (interest rate) sebesar $12 \%$. Pendapatan (revenue) yang diharapkan sebesar Rp. 20 milyar setiap tahun.

PV dari proceeds

20.000.000.000

PV dari outlays

Profitability Index

: Rp. 60 Milyar

Perhitungan dengan metode Profitability Indeks sebesar 1,656 $>1$ maka pembangunan Tower Hotel dan Restaurant "Golf View" dapat dilanjutkan dan menguntungkan.

\section{IV.4. ANALISIS DATA}

IV.4.1. AKTIVA LANCAR

Pada pos aktiva lancar di Laporan Keuangan XYZ Hotel terjadi perubahan 
yang cenderung adanya kenaikan aktiva lancar dari tahun 2012 sampai 2013 sebesar 33,08\% kemudian di tahun 2014 menurun sebesar $28,58 \%$.

\section{IV.4.2. AKTIVA TETAP}

Tabel 10 Current Asset Neraca Hotel XYZ

\begin{tabular}{|c|c|c|c|}
\cline { 2 - 4 } \multicolumn{1}{c|}{$31 / 122012$} & $31 / 122013$ & $31 / 122014$ \\
\hline Total Current Assets & $34,012,002,478$ & $45,262,443,747$ & $32,328,110,001$ \\
\hline
\end{tabular}

Pada pos aktiva tetap terjadi perubahan kenaikan sebesar Rp. 11,25 milyar $(33,08 \%)$ pada tahun 2013 kemudian di tahun 2014 ada penurunan sebesar Rp. 12,93 milyar (28,58\%). Kondisi ini disebabkan adanya peningkatan investasi berupa penambahan Deposito Bank Rp. 10,19 milyar di tahun 2014 serta penurunan jumlah Piutang (Account Receivable) Hotel XYZ sebesar Rp. 29,3 Milyar (83,80\%) di tahun 2014 atas meningkatkan kinerja mencapai tujuan yang diharapkan.

\section{IV.4.3. AKTIVA LAINNYA}

Tabel 11. Aktiva Tetap Neraca Hotel XYZ

\begin{tabular}{|l|c|c|c|}
\cline { 2 - 4 } \multicolumn{1}{c|}{} & $31 / 12 / 2012$ & $31 / 12 / 2013$ & $31 / 12 / 2014$ \\
\hline Total Altiva Tetap & $83,774,181,839$ & $80,794,907,435$ & $78,748,290,552$ \\
\hline
\end{tabular}

Pada pos aktiva lainnya terjadi penurunan sebesar Rp. 2,98 milyar (3,56\%) tahun 2013 dan terjadi penurunan sebesar Rp. 2 milyar (2,53\%) di tahun 2014. Kondisi ini disebabkan adanya peningkatan akumulasi penyusutan sebesar Rp. 7,34 milyar di tahun 2013 dan peningkatan jumlah akumulasi penyusutan Hotel XYZ sebesar Rp. 6,35 milyar di tahun 2014 atas meningkatkan pembelian aset yang yang umur penggunaannya di bawah 5 tahun.

\section{IV.4. KEWAJIBAN LANCAR}

Tabel 12.Current Liabitilies Neraca Hotel XYZ

\begin{tabular}{|c|c|c|c|}
\cline { 2 - 4 } \multicolumn{1}{c|}{} & $31 / 12 / 2012$ & $31 / 12 / 2013$ & $31 / 122 / 2014$ \\
\hline Total Current Liabilities & $13,185,448,942$ & $16,453,225,317$ & $13,496,344,415$ \\
\hline
\end{tabular}
kenaikan sebesar Rp. 3,26 milyar (24,78\%) tahun 2013 dan terjadi penurunan sebesar Rp. 2,96 milyar (17,97\%) di tahun 2014. Kenaikan disebabkan adanya peningkatan biaya yang masih harus dibayar tahun 2013 sebesar Rp. 8,1 milyar (537,9\%) dan peningkatan biaya yang masih harus dibayar tahun 2014 sebesar Rp. 656,73 juta $(6,83 \%)$.

\section{IV.5. KEWAJIBAN JANGKA \\ PANJANG}

Pada pos kewajiban jangka panjang terdapat kenaikan sebesar Rp. 21,24 milyar di tahun 2013 dan penurunan sebesar Rp. 8,53 milyar di tahun 2014. Kondisi ini memperlihatkan pada tahun 2013 Hotel XYZ melakukan pinjaman investasi ke Bank sebesar Rp. 21,24 milyar dan dapat melakukan pengembalian ke Bank sebesar Rp. 8,53 milyar (40,18\%) di tahun 2014 atas meningkatnya keuntungan dari Hotel.

\section{IV.6. BIAYA VARIABEL}

Tabel 13. Biaya Variabel Laba (Rugi) Hotel XYZ

\begin{tabular}{c|c|c|c|c}
\hline $\begin{array}{c}\text { Keterangan } / \\
\text { Tahun }\end{array}$ & $\mathbf{3 1 / 1 2 / 1 3}$ & $\mathbf{3 1 / 1 2 / 1 4}$ & Kenaikan & $\%$ \\
\hline Biaya Variabel & $24,956,954,242$ & $22,310,347,105$ & $(2,646,607,137)$ & $-10.60 \%$ \\
\hline
\end{tabular}

Pada pos biaya variable terdapat penurunan sebesar Rp. 2,64 milyar (10,6\%) di tahun 2014. Kondisi ini disebabkan antara lain adanya penurunan Biaya Perawatan sebesar Rp. 2,23 milyar (47,86\%) dan penurunan Biaya Listrik sebesar Rp. 658,86 juta $(12,14 \%)$.

\section{IV.7. BIAYA TETAP LANGSUNG}

Tabel 14. Biaya Tetap Langsung Laba (Rugi) Hotel XYZ

\begin{tabular}{|l|c|c|c|c|}
\hline $\begin{array}{c}\text { Keterangan / } \\
\text { Tahun }\end{array}$ & $31 / 12 / 13$ & $31 / 12 / 14$ & Kenaikan & $\%$ \\
\hline $\begin{array}{l}\text { Biaya tetap } \\
\text { langsung }\end{array}$ & $13,330,119,122$ & $14,287,750,634$ & $957,631,512$ & $7.18 \%$ \\
\hline
\end{tabular}


Pada pos biaya tetap langsung terdapat kenaikan sebesar Rp 957,63 juta (7.18\%) di tahun 2014. Kondisi ini disebabkan antara lain adanya kenaikan Biaya Tenaga Kerja sebesar Rp. 761,87 juta $(12,12 \%)$ dan kenaikan Biaya Perkantoran \& Umum sebesar Rp. 108,4 juta (51,21\%).

\section{IV.8. BIAYA ADMINISTRASI \& UMUM}

Tabel 15. Biaya Adm \& Umum Laba (Rugi) Hotel XYZ

\begin{tabular}{c|c|c|c|c}
\hline $\begin{array}{c}\text { Keterangan } \\
\text { Tahun }\end{array}$ & $31 / 12 / 13$ & $31 / 12 / 14$ & Kenaikan & $\%$ \\
\hline $\begin{array}{c}\text { Biaya Administrasi } \\
\& \text { Umum }\end{array}$ & $5,900,651,185$ & $6,528,759,015$ & $628,107,830$ & $10.64 \%$ \\
\hline
\end{tabular}

Pada pos biaya administrasi \& umum terdapat kenaikan sebesar Rp 628,1 juta $(10,64 \%)$ di tahun 2014. Kondisi ini disebabkan antara lain adanya kenaikan Biaya Tenaga Kerja sebesar Rp. 535,3 juta $(11,22 \%)$ dan kenaikan Biaya Perkantoran \& Umum sebesar Rp. 261,3 juta (44\%).

\section{IV.9. BIAYA PEMASARAN}

Tabel 16. Biaya Pemasaran Laba (Rugi) Hotel XYZ

\begin{tabular}{|c|c|c|c|c}
\hline $\begin{array}{c}\text { Keterangan } / \\
\text { Tahun }\end{array}$ & $31 / 12 / 13$ & $31 / 12 / 14$ & Kenaikan & $\%$ \\
\hline Biaya Pemasaran & $1,640,966,868$ & $1,787,351,087$ & $146,384,219$ & $8.92 \%$ \\
\hline
\end{tabular}

Pada pos biaya pemasaran terdapat kenaikan sebesar Rp 146,38 juta (8,92\%) di tahun 2014. Kondisi ini disebabkan antara lain adanya kenaikan Biaya Tenaga Kerja sebesar Rp. 80,4 juta $(11,6 \%)$ dan kenaikan Biaya Training sebesar Rp. 15,8 juta $(100 \%)$.

\section{PEMBAHASAN HASIL PENELITIAN}

Analisis atas Laporan Keuangan 20122014 terkait dengan kelayakan investasi yang dilakukan telah menjawab permasalahan yang disampaikan di awal yaitu :
1. Terdapat kenaikan keuntungan (profit) mulai tahun 2012 sampai dengan tahun 2014 atas pembangunan Tower Hotel XYZ dan restaurant "Golf View".

Penambahan jumlah kamar dan restaurant memberikan kontribusi kenaikan laba bersih Hotel XYZ tahun 2013 sebesar Rp. 6.498.101.832 setara dengan kenaikan 182,5\% dari laba bersih tahun 2012. Terlihat di Laporan Keuangan bahwa terjadi sedikit penurunan laba bersih (net profit) di tahun 2014 sebesar Rp. 1.302.315.163 setara dengan penurunan 12,95\% dari laba bersih tahun 2013. Penurunan laba bersih (net profit) tahun 2014 lebih banyak disebabkan penurunan pendapatan (revenue) sebesar Rp. 1,36 milyar (2,40\%), kenaikan biaya pemasaran 628 juta $(10,64 \%)$ disebabkan hadirnya beberapa Hotel sekelas di Kota Cilegon yang memberikan potongan harga khusus. Kondisi ini mengakibatkan beberapa corporate customer Hotel XYZ berpindah ke Hotel yang lebih murah dan bangunan baru.

2. Pengaruh investasi pembangunan Tower Hotel (89 rooms) dan Restaurant "Golf View" menaikkan tingkat hunian kamar, meningkatnya tarif sewa kamar, bertambahnya pendapatan (revenue), meningkatnya kemampuan Hotel XYZ dalam mengembalikan investasi walaupun adanya kenaikan suku bunga pinjaman Bank.

3. Analisis atas Laporan Keuangan tahun 2012 - 2014 memperlihatkan adanya peningkatan tingkat hunian 105.193 kamar tahun 2013 dan 114.496 kamar tahun 2014.

4. Analisis atas Laporan Keuangan tahun 2012 - 2014 memperlihatkan adanya perubahan kenaikan rata-rata tarif sewa kamar Rp. 525.000 tahun 2012, Rp. 
637.519 dan tahun 2013, Rp. 756.689,

5. Kenaikan pendapatan (revenue) tahun 2013 sebesar Rp. 34,47 milyar (139,68 \%) dan tahun 2014 kenaikan sebear Rp. (131,55 \%) dibandingkan periode Laporan Keuangan tahun 2012.

6. Kenaikan tingkat hunian, kenaikan rata-rata tarif sewa kamar dan kenaikan pendapatan (revenue) atas sewa kamar menjadikan meningkatnya kemampuan Hotel XYZ dalam mengembalikan investasi walaupun adanya kenaikan suku bunga pinjaman Bank.

7.Investasi pembangunan Tower Hotel (89 rooms) dan Restaurant "Golf View" dapat menambah kontribusi keuntungan sesuai Studi Kelayakan Investasi terhadap profitabilitas Hotel $\mathrm{XYZ}$ dengan menggunakan metode NPV, BEP, IRR, RCR, ROI, ROE, $\mathrm{CBR}$ dan Profitability Index.

Analisis kelayakan investasi yang diperhitungkan adalah :

8. $\mathrm{NPV}=$ Rp. 99,36 Milyar - Rp. 60 Milyar $=$ Rp. 39,36 milyar

9. NPV $>0$ maka investasi dengan NPV Rp. 39,36 milyar dapat dilanjutkan / diterima

10.Break event point (BEP) selama 8 TAHUN 16 HARI terhadap ionvestasi yang telah dilakukan,

11.Metode Internal Rate of Return (IRR) digunakan untuk menganalisis besarnya tingkat bunga yang menjadikan biaya pengeluaran dan pemasukan sama besarnya IRR Hotel XYZ 15,87\% > 8,5\% (interest deposit bank) dimana IRR > i (suku bunga), sehingga usulan investasi diterima,

12.Metode RCR (Revenue Cost Ratio) sebesar 1,17 pada tahun 2012, sebesar 1,20 pada tahun 2013 dan sebesar 1,38 tahun 2014 yang menjelaskan bahwa $\mathrm{R} / \mathrm{C}>1$ menguntungkan setelah proyek.

13.Metode ROI (Return on Investment) sebesar 5,93\% tahun 2012 dan 15,65\% tahun 2013 serta $12,67 \%$ tahun 2014 yang menjelaskan bahwa terjadi peningkatan kemampuan Hotel XYZ dalam memperoleh laba operasi dari modal yang diinvestasikan dalam keseluruhan aktiva.

14. Metode ROE (Return on Equity) sebesar 3,51\% tahun 2012 dan 12,82\% tahun 2013 serta $13,81 \%$ tahun 2014 yang menjelaskan bahwa terjadi peningkatan kemampuan Hotel XYZ dalam memperoleh laba bersih dari modal yang disetor.

15.Perhitungan dengan Metode CBR (Cost Benefit Ratio) menyatakan bahwa hasil CBR $>1$ maka pembangunan Tower Hotel dan Restaurant "Golf View" dapat diterima / dilanjutkan.

16.Perhitungan dengan metode Profitability Indeks (PI) sebesar 1,656 $>1$ maka pembangunan Tower Hotel dan Restaurant "Golf View" dapat dilanjutkan dan menguntungkan.

Dengan naiknya semua bahan pokok langsung maupun tidak langsung akan berdampak terhadap kenaikan biaya operasional Hotel. Apabila tidak diimbangi dengan kenaikan penjualan (sales) kondisi ini dapat berakibat menurunnya keuntungan (profit) hotel.

\section{SIMPULAN DAN REKOMENDASI VI.1. SIMPULAN}

Hasil analisis atas kelayakan investasi berupa pembangunan Tower Hotel XYZ dan Restaurant "Golf View" di Hotel XYZ di tahun 2012 berdasarkan Laporan Keuangan 3 tahun terakhir adalah sebagai berikut :

1. Terdapat kenaikan keuntungan (profit) 
mulai tahun 2012 sampai dengan tahun 2014. Kenaikan keuntungan bersih (net profit) Hotel XYZ tahun 2013 sebesar Rp. 6.498.101.832 setara dengan kenaikan $182,5 \%$ dari laba bersih tahun 2012, terjadi sedikit penurunan laba bersih di tahun 2014 sebesar Rp. 1.302.315.163 setara dengan penurunan $12,95 \%$ dari laba bersih tahun 2013 .

2. Analisis atas Laporan Keuangan tahun 2012 - 2014 memperlihatkan adanya peningkatan tingkat hunian 105.193 kamar tahun 2013 dan 114.496 kamar tahun 2014.

3. Analisis atas Laporan Keuangan tahun 2012 - 2014 memperlihatkan adanya perubahan kenaikan rata-rata tarif sewa kamar Rp. 525.000 tahun 2012, Rp. 637.519 dan tahun 2013, Rp. 756.689,-

4. Kenaikan pendapatan (revenue) tahun 2013 sebesar Rp. 34,47 milyar (139,68 \%) dan tahun 2014 kenaikan sebear Rp. (131,55 \%) dibandingkan periode Laporan Keuangan tahun 2012.

5. Adanya peningkatan kemampuan pengembalian investasi diatas kenaikan suku bunga pinjaman Bank. Hal ini dapat terlihat di Laporan Keuangan bahwa Pihak Hotel XYZ telah melakukan pengembalian Hutang jangka Panjang nya sebesar Rp. 8,53 milyar (40,18\%) di tahun 2014.

Dari beberapa metode perhitungan rasio dan beberapa pendekatan terkait dengan investasi pembangunan Tower Hotel dan Restaurant yang telah dilakukan terdapat perhitungan dengan metode menjelaskan bahwa invetasi dapat diterima dan dapat dilanjutkan. Analisis kelayakan investasi yang diperhitungkan adalah :

1. NPV $>0$ maka investasi dengan NPV
Rp. 39,36 milyar dapat dilanjutkan / diterima

2. Break event point (BEP) selama 8 TAHUN 16 HARI,

3. Internal Rate of Return (IRR) Hotel XYZ 15,87\% > 8,5\% (interest deposit bank) dimana IRR $>$ i (suku bunga).

4. Metode RCR (Revenue Cost Rasio) sebesar 1,17 pada tahun 2012, sebesar 1,20 pada tahun 2013 dan sebesar 1,38 tahun 2014.

5. Metode ROI (Return on Investment) sebesar 5,93\% tahun 2012 dan 15,65\% tahun 2013 serta 12,67\% tahun 2014 .

6. Metode ROE (Return on Equity) sebesar 3,51\% tahun 2012 dan 12,82\% tahun 2013 serta 13,81\% tahun 2014.

7. Perhitungan dengan Metode CBR (Cost Benefit Ratio) menyatakan bahwa hasil CBR $>1$ maka pembangunan Tower Hotel dan Restaurant "Golf View" dapat diterima / dilanjutkan.

8. Perhitungan dengan metode Profitability Indeks (PI) sebesar 1,656 $>1$ maka pembangunan Tower Hotel dan Restaurant "Golf View" dapat dilanjutkan dan menguntungkan.

\section{VI.2. REKOMENDASI}

Adapun saran yang dapat meningkatkan dan mempertahankan kinerja Hotel yaitu:

1. Melakukan efisiensi beberapa fasilitas yang kurang memberikan kontribusi pendapatan (revenue) bagi Hotel XYZ.

2. Melakukan perbedaan yang lebih menonjol dari Hotel lainnya untuk disampaikan ke customer Hotel yang loyal dengan cara yang lebih tepat sasaran.

3. Meningkatkan pelayanan dan kompetensi SDM terkait dengan 
pelatihan terbaru agar menciptakan daya saing diantara Hotel lainnya.

4. Mempergunakan lebih banyak tenaga muda yang lebih energik sehingga biaya (cost) efisien khususnya tenaga penjualan (sales) dan pemasaran (marketing) sehingga dapat meningkatkan pendapatan (revenue) antara lain dengan tidak hanya bergantung pada penjualan kamar.

5. Melakukan rotasi maupun mutasi dalam struktur organisasi dengan tenaga kerja/ karyawan yang kompeten di bidangnya.

6. Melakukan perhitungan ulang atas biaya (cost) yang kurang tepat sasaran.

7. Penentuan tarif kamar maupun special treatment guna lebih memberikan daya saing khususnya untuk jenis kamar yang kurang memberikan peningkatan pendapatan (revenue).

8. Melakukan perhitungan lebih detail untuk investasi yang tidak produktif dengan cara alih fungsi ataupun memberi nilai tambah (value added).

\section{DAFTAR PUSTAKA}

Ambarwati (2010), Manajemen Keuangan Lanjut. Graha Ilmu, Yogyakarta: Indonesia.

Agin (2012), Pengaruh Tingkat Hunian pada Keputusan Investasi Proyek Hotel Santika Gubeng Surabaya. Jurnal teknik ITS, Vol. 1, No. 1, pp. 93-96.

Christanti (2011), Faktor-Faktor Yang Dipertimbangkan Investor Dalam Melakukan Investasi. Jurnal Manajemen Teori dan Terapan, No. 3, pp. 37-51.

Darminto (2005), Analisis Laporan Keuangan Hotel. Andi, Yogyakarta: Indonesia.
Fahmi (2012), Analisis laporan Keuangan (Cetakan ke-2). Alfabeta, Bandung: Indonesia.

Fayol (2012), Industri dan Manajemen Umum (Terj. Winardi). Sir Issac and Son, London: UK.

Ficka(2012), Analisis Kelayakan Finansial Usaha Penangkapan Ikan Menggunakan Panah Dan Bubu Dasar Di Perairan Karimunjawa, Journal of Fisheries Resources Utilization Management and Technology, Vol. 1, No. 1, pp. 22-31.

Gitosudarmo (2012), Manajemen Keuangan. (Edisi-4). BPFE, Yogyakarta: Indonesia

Husnan (2000), Manajemen Keuangan: Teori dan Penerapan (Keputusan Jangka Panjang). Jilid 1 dan 2. (Edisi ke-4), BPFE, Yogyakarta: Indonesia.

Husnan (2010), Studi Kelayakan Proyek (Edisi Ke-4). UPP STIM YKPN, Yogyakarta: Indonesia.

Ibrahim (2009), Studi Kelayakan Bisnis (Edisi Revisi). PT. Rineka Cipta, Jakarta: Indonesia.

Ibrahim (2009), Studi Kelayakan Bisnis. PT Rineka Cipta, Jakarta: Indonesia.

Indonesia. Keputusan Menteri Kebudayaan dan Pariwisata No. KM 3/HK 001/MKP 02: Penggolongan kelas hotel. Semarang: Kementerian Kebudayaan dan Pariwisata, 2002.

Imam (2013), Manajemen Proyek (Edisi Ke-2). Erlangga, Jakarta: Indonesia.

Johan (2011), Studi Kelayakan Pengembangan Bisnis. Graha Ilmu, Yogyakarta: Indonesia.

Kasmir (2010) Studi Kelayakan Bisnis. Kencana Prenada Media Grup, Jakarta: Indonesia. 
Mamduh (2009), Analisis Laporan Keuangan. UPP AMP YKPN, Yogyakarta: Indonesia.

Musgrove (2010), Public Finance in Theory and Practice. Mc Graw Hill, New York: USA.

Ofianto (2014), Analisis Investasi pada Proyek Pembangunan Apartemen Bale Hinggil Surabaya. Jurnal Teknik POM ITS, Vol. 3, No.1, pp. 41-46.

Putra (2013), Analisis Pembiayaan Investasi Proyek Apartemen Kertajaya. Jurnal Teknik ITS, Vol.2, No. 1.

Sartono, Agus (2008), Manajemen Keuangan Teori dan Aplikasi, BPFE, Yogyakarta: Indonesia.

Steven (2013), Analisis Biaya Investasi Pada Perumahan Griya Paniki Indah. Jurnal Sipil Statik Vol.1 No.5, pp. 377381.

Subagyo, Ahmad (2007), Studi Kelayakan. Elex Media Komputindo, Jakarta: Indonesia.
Sulisyanto (2011), Studi Kelayakan Bisnis. Andi, Yogyakarta: Indonesia.

Suratman (2010), Studi Kelayakan Proyek, Teknik dan Prosedur Penyusunan Pelaporan. J\&J Learning, Yogyakarta: Indonesia.

Sutrisno (2009), Manajemen Keuangan Teori, Konsep dan Aplikasi. Ekonisia Fakultas Ekonomi UII, Yogyakarta: Indonesia.

Terry (2009), Dasar-Dasar Manajemen (Terj. Ticoalu) (Cetakan ke-11). Bumi Aksara, Jakarta: Indonesia.

Wijayanti (2008), Manajemen. Mitra Cendekia Press, Yogyakarta: Indonesia.

Wiyasha (2007), Akuntansi Manajemen untuk Hotel dan Restoran. Andi, Yogyakarta: Indonesia. 